\title{
INVESTIGATION OF SURFACE ROUGHNESS AND MICROHARDNESS IN BALL BURNISHING PROCESS OF AZ31B MAGNESIUM ALLOY
}

\author{
Berat Baris BULDUM \\ ${ }^{1}$ Mersin University, Department of Mechanical Engineering, Mersin, TURKEY \\ 1barisbuldum@mersin.edu.tr
}

(Geliş/Received: 07.06.2017; Kabul/Accepted in Revised Form: 12.07.2017)

\begin{abstract}
Magnesium alloys which are lightweight and high strength materials have some limitations due to their insufficient corrosion resistance and low surface quality. To overcome these limitations, especially improving surface properties ball burnishing process was applied to magnesium alloy with different parameters like force, number of passes, feed rate and speed. For reducing number of experiments Taguchi method was used and optimum burnishing condition was determined according to $\mathrm{S} / \mathrm{N}$ ratios. The results of surface roughness and hardness tests show that feed rate and force was found significant parameters for improving surface quality. When lower feed rate and higher force parameters was choosen best surface roughness value was obtained.
\end{abstract}

Key Words: Ball Burnishing, Magnesium alloy, Surface roughness, Taguchi.

\section{AZ31B Magnezyum Alaşımının Bilyalı Parlatma Yöntemi ile Mikrosertlik ve Yüzey Pürüzlülüğünün Araştırılması}

ÖZ: Hafif ve yüksek dayanımlı malzemelerden olan magnezyum alaşımları, yetersiz korozyon direnci ve düşük yüzey kalitesi nedeniyle bazı sınırlamalara sahiptir. Bu sınırlamaların üstesinden gelmek, özellikle yüzey özelliklerini iyileştirmek için, ilerleme hızı, devir, kuvvet ve paso sayısı gibi farklı parametrelerle bilyalı parlatma işlemi uygulanmıştır. Deney sayısını azaltmak için Taguchi yöntemi kullanılmış ve S/N oranlarına göre en iyi parlatma koşulları belirlenmiştir. Yüzey pürüzlülügü ve sertlik testlerinin sonucunda ilerleme hızı ve kuvvetin yüzey kalitesini iyileştirmede önemli parametreler olduğu bulunmuştur. Düşük ilerleme hızı ve yüksek kuvvet parametreleri seçildiğinde en iyi yüzey pürüzlülüğü değeri elde edilmiştir.

Anahtar Kelimeler: Bilyalı Parlatma, Magnezyum alaşımı, Yüzey pürüzlülüğ̈̈̈, Taguchi

\section{INTRODUCTION}

Magnesium is of interest as a construction material because of its very low density and good strength. Magnesium alloys are very attractive materials for engineering applications, such as biomaterial, automobile and aero industries due to their advantages like lightweight, high strength and high specific stiffness. Thus, they have recently been increasing the interest as base materials in many applications, in particular, they are considered to be replacing aluminum alloys in the automotive industries (Cui et al., 2015; Fouad, 2011). The attractive mechanical properties of $\mathrm{Mg}$ and its alloys increase their use in industry but, their applications are often limited because of their unsatisfactory corrosion performance and poor surface properties. To overcome the limitation of these deficiencies, the surface properties of $\mathrm{Mg}$ alloys, therefore need to be improved. Surface modification is a common way to improve the surface properties. Surface properties have, importance for better product life of several 
machines and structural parts that are used for engineering applications (Fouad and El Batanouny, 2011; Pu et al., 2012)

Nowadays manufacturing industry is showing more interest in dimensional precision and surface treatments. Schematic representation of the formation of surface roughness was shown in figure 1. To improve product quality, traditional surface treatments like honing, grinding and lapping are used. But these chip removal processes depend on skill and experience of the operator. To overcome these problems, ball burnishing process is used for better surface roughness which is chip-less, simple and short processing times application. Ball burnishing is a cold working process that obtains better surface roughness using plastic deformation without material loss (Aldas et al., 2014; Kulekci et al. ,2014; John et al., 2016; Sagbas, 2011).

Burnishing is a surface finish treatment to cause residual stresses on material surfaces and to improve surface qualities. The enhancement in surface values include increase in surface hardness, reduction in surface roughness, the production of compressive residual stresses which are favorable for cold work hardening of the surface, improves tensile strength and corrosion resistance, also maintains dimensional stability fatigue life as result of the produced compressive residual stress (Hassan et al., 1996; Revankar et al., 2014).

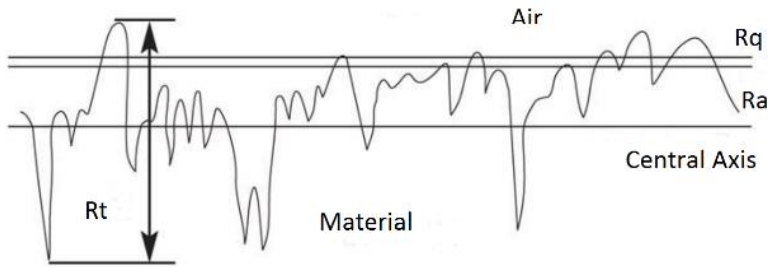

Figure 1. Schematic representation of the formation of surface roughness (Hiegemann et al., 2016)

Hassan et al. were used ball-burnishing process in order to improve the surface hardness and roughness of brass alloys. They were investigated the effect of different forces and a number of tool passes. The results obtained from the wear tests show that the burnishing process was improved the wear resistance of the brass alloys (Hassan and Al-Dhifi, 1999). El-Axira et al. were studied four ball burnishing parameters for aluminum alloy 2014 which is the depth of penetration, feed rate, a number of passes and burnishing speed. A remarkable increasing surface microhardness in specimens was obtained (El Axir et al., 2008). Hassan et al. were examined the surface roughness, proof stress, hardness, fatigue strength and ultimate tensile before and after burnishing properties of non-ferrous metals. The results were showed some recuperation on these properties due to the burnishing process (Hassan and Al-Bsharat, 1996). Shiou et al. were investigated the optimal surface parameters for the NAK80 mold tool steel via using the Taguchi's L18 orthogonal table. The burnished surface roughness of the samples were enhanced from about $\mathrm{Ra} 0.06 \mu \mathrm{m}$ to $0.016 \mu \mathrm{m}$ in average using the determined optimal parameters (Shiou and Cheng, 2008). Hassan et al. were studied the effects of the force and the number of passes on the surface hardness and roughness of aluminum and brass. They were obtained that improvements in the surface roughness and increases in the surface hardness values (Hasan, 1997). Rodriguez et al. was used a finite element model of ball-burnishing to find out and estimate residual stress values. They were found that burnishing is an economical and possible process for the quality improvement of materials, not only in surface roughness but in compressive residual stresses as well (Rodriguez et al., 2012).

The scope of this investigation optimum burnishing parameters of AZ31B mg alloys were determined. The effects of different passes, forces, feed rate, and speed were examined using Taguchi method. 


\section{MATERIAL AND METHOD}

In this study, AZ31B Mg alloys were used as a workpiece material. The chemical composition of this alloy is as shown in Table 1. AZ31B was choosen because of magnesium alloys are very attractive materials for engineering applications, such as biomaterial, automobile and aero industries due to their advantages like lightweight, high strength and high specific stiffness.

\section{Design of the Taguchi's Orthogonal Array}

The traditional experiments process are too complicated and not easy to use. And also machining process period is important for manufacturer. When the number of parameters is more a large number of experiments have to be realized. Because of this problems Taguchi leads the use of orthogonal arrays to research all parameters with a small number of experiments. Taguchi proposed signal to noise $(\mathrm{S} / \mathrm{N})$ ratio for defining optimum parameters of experiments. Experiments design problems can be divided into the smaller the better type, the larger the better type and the nominal the-best type. The signal to noise $(\mathrm{S} / \mathrm{N})$ ratio was used for optimizing a treatment for product design.

Table 1. Chemical composition of AZ31B Mg alloy

\begin{tabular}{|llllllll|}
\hline Component & Al & Zn & Mn & Fe & Si & $\mathbf{C u}$ & Ni \\
\hline$\%$ & 8.73 & 0.56 & 0.23 & 0.0026 & 0.021 & 0.0018 & 0.0009 \\
\hline
\end{tabular}

The surface roughness value of the burnished surface throughout the optimum parameters should be smaller than nonburnished surface and the hardness value should be bigger than nonburnished surface. Consequently, for surface roughness smaller the better type (equation 1), for surface hardness larger the better type (equation 2 ) is available. The $S / N$ ratio, $\eta$, is defined by the following equations:

$\eta=-10 \log _{10}\left[\frac{1}{n} \sum_{i=1}^{n} y_{i}^{2}\right]$

$\eta=-10 \log _{10}\left[\frac{1}{n} \sum_{i=1}^{n} \frac{1}{y_{i}^{2}}\right]$

where $n$ is the number of the experiment and $y i$ is the results of the experiments under different parameters (El Axir and Ibrahim, 2005; Shiou and Hsu, 2008; Ibrahim et al., 2009; Gomez-Gras et al., 2015).

The effects of some parameters can be determined efficiently using Taguchi design. The essential burnishing parameters having important effects on surface roughness are speed, feed rate, forces and a number of passes. Consequently, speed, feed rate, a number of passes and force, were selected as four experimental parameters (Table 2). Two levels for a number of passes and three level of other parameters (feed rate, speed, force) were selected. The L18 orthogonal array (Table 3) was choosen for one two level and three three-level factors of the ball burnishing process.

\section{Sample and Analyses}

AZ31B Mg alloys (Yuanhong Alloy Materials Co.,Ltd, China), were used in the experiments, which was commercially bought as $50 \mathrm{~mm}$ diameter and approximate length of $300 \mathrm{~mm}$ bars to using a test specimen. Samples were cut from these bars, then each sample was machined to a diameter of $25 \mathrm{~mm}$ and divided into nine regions. The burnishing tool was attached to a Liouy Hsing GNC-450L CNC lathe 
(figure 2), which the operation is performed. Four parameters were adjusted for experiments. Then burnishing process are carried out on the turned surface by varying the force (50, 150, $250 \mathrm{~N}$ ), feed rate $(0.1,0.25,0.5 \mathrm{~mm} / \mathrm{dk})$, speed $(200,400,600 \mathrm{rpm})$, a number of passes.

Table 2. The value of using parameters for ball burnishing process

\begin{tabular}{|c|c|c|c|}
\hline $\mathrm{P}$ & $F(\mathrm{~N})$ & V (rpm) & $\mathrm{f}(\mathrm{mm} / \mathrm{min})$ \\
\hline 1 & 50 & 200 & 0.1 \\
\hline 2 & 150 & 400 & 0.25 \\
\hline- & 250 & 600 & 0.5 \\
\hline
\end{tabular}

Therefore, nine burnishing operations were developed for each of the two specimens. The surface roughness of all the burnished work pieces was determined using surface roughness tester (Mitutoyo, Surftest SJ 201). To determining surface roughness quality, three mesurements were taken at different points of the specimen in Ra $(\mu \mathrm{m})$ values and their averages were calculated. The hardness of each sample was determined using vickers test machine (Tronic, Digital Microhardness Tester DHV-1000). Testing load of $1 \mathrm{~kg}$ load was applied.

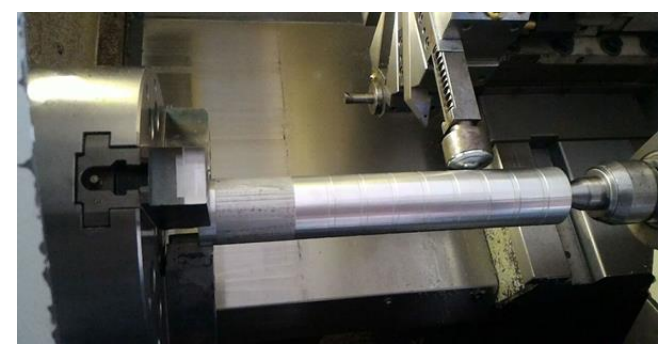

Figure 2. The photograph of the AZ31B Mg alloy ball burnishing process

The solid model of the ball burnishing tool is shown in figure 3a. The schematic view of work piece material shown in figure 3b.Figure. $4 \mathrm{a}$ and Figure $4 \mathrm{~b}$ show the photographs of the surface roughness tester and vickers hardness machine used in the present work.

Table 3. Taguchi design of experiments

\begin{tabular}{|l|cccc|}
\hline & $\mathbf{P}$ & $\mathbf{F} \mathbf{( N )}$ & $\mathbf{V}(\mathbf{r p m})$ & $\mathbf{f}(\mathbf{m m} / \mathbf{d k})$ \\
\hline $\mathbf{1}$ & 1 & 1 & 1 & 1 \\
$\mathbf{2}$ & 1 & 1 & 2 & 2 \\
$\mathbf{3}$ & 1 & 1 & 3 & 3 \\
$\mathbf{4}$ & 1 & 2 & 1 & 1 \\
$\mathbf{5}$ & 1 & 2 & 2 & 2 \\
$\mathbf{6}$ & 1 & 2 & 3 & 3 \\
$\mathbf{7}$ & 1 & 3 & 1 & 2 \\
$\mathbf{8}$ & 1 & 3 & 2 & 3 \\
$\mathbf{9}$ & 1 & 3 & 3 & 1 \\
$\mathbf{1 0}$ & 2 & 1 & 1 & 3 \\
$\mathbf{1 1}$ & 2 & 1 & 2 & 1 \\
$\mathbf{1 2}$ & 2 & 1 & 3 & 2 \\
$\mathbf{1 3}$ & 2 & 2 & 2 & 2 \\
$\mathbf{1 4}$ & 2 & 2 & 3 & 3 \\
$\mathbf{1 5}$ & 2 & 2 & 1 & 1 \\
$\mathbf{1 6}$ & 2 & 3 & 2 & 3 \\
$\mathbf{1 7}$ & 2 & 3 & 3 & 1 \\
$\mathbf{1 8}$ & 2 & 3 & & 2 \\
\hline
\end{tabular}


a)

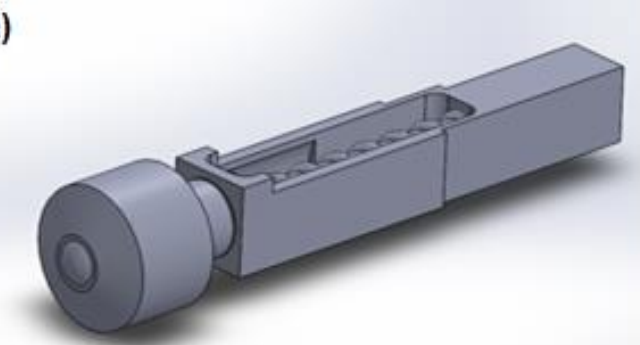

b)

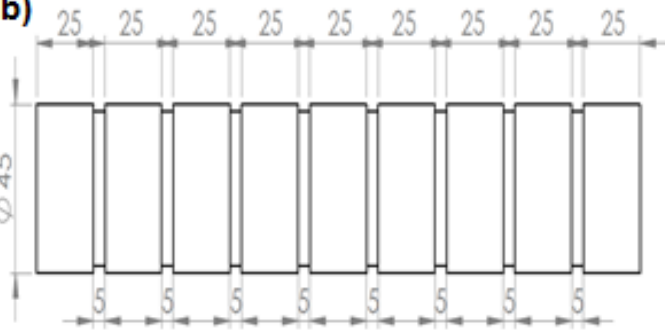

Figure 3. a) Solid model of ball burnishing tool b) Schematic view of the specimens

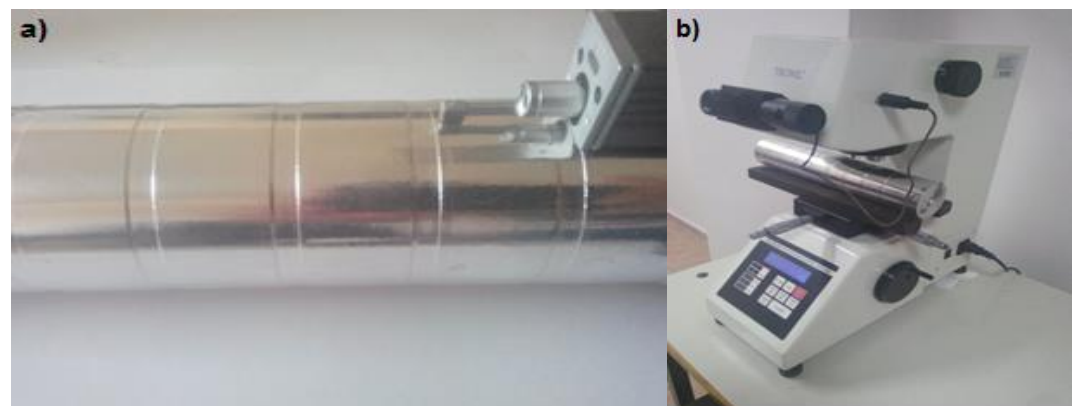

Figure 4. a) The photograph of the surface roughness measuring test b) The photograph of the Vickers microhardness test

\section{RESULT AND DISCUSSION}

In the present study the effect of the different parameters (force, speed, feed rate and number of passes) on surface roughness and vickers hardness of AZ31B $\mathrm{Mg}$ alloys were performed. For investigating feed rate, speed and force three different level were applied. For number of passes 1 and 2 passes were studied. Researching all this parameters 54 experiments were required. But using Taguchi experimental design the study was made efficient. 3 factor 3 level and 1 factor 2 level Taguchi mixed design were selected. By this way number of experiment were reduced from 54 to 18 using $\mathrm{L}_{18}$ orthogonal array.

$\mathrm{S} / \mathrm{N}$ values were calculated for defining optimum parameters of burnishing process. Smaller is the better type were used for surface roughness and larger is the better type were used for vickers hardness. Taguchi L18 orthogonal array design, surface roughness and hardness values also $\mathrm{S} / \mathrm{N}$ ratios are seen in Table 4. 
Table 4. Taguchi L18 orthogonal array, measured values and $\mathrm{S} / \mathrm{N}$ ratios

\begin{tabular}{|c|cccccccc|}
\hline $\begin{array}{c}\text { Num. } \\
\text { Of } \\
\text { exp. }\end{array}$ & Passes & $\begin{array}{c}\text { Force } \\
\text { (N) }\end{array}$ & $\begin{array}{c}\text { Speed } \\
\text { (rpm) }\end{array}$ & $\begin{array}{c}\text { Feed rate } \\
\text { (mm/dk) }\end{array}$ & $\begin{array}{c}\text { Surface } \\
\text { rough. }\end{array}$ & $\begin{array}{c}\text { Hardness } \\
\text { (HV) }\end{array}$ & $\begin{array}{c}\text { S/N ratio } \\
\text { of surface } \\
\text { rough. }\end{array}$ & $\begin{array}{c}\text { S/N ratio } \\
\text { of } \\
\text { hardness }\end{array}$ \\
\hline 1 & 1 & 50 & 200 & 0.1 & 0.483 & 81.273 & $6.31 \mathrm{~B} 2$ & 47.763 \\
2 & 1 & 50 & 400 & 0.25 & 0.551 & 79.097 & 5.155 & 47.520 \\
3 & 1 & 50 & 600 & 0.5 & 0.677 & 82.953 & 3.390 & 47.921 \\
4 & 1 & 150 & 200 & 0.1 & 0.355 & 79.810 & 8.990 & 47.602 \\
5 & 1 & 150 & 400 & 0.25 & 0.475 & 82.870 & 6.466 & 47.920 \\
6 & 1 & 150 & 600 & 0.5 & 0.639 & 81.360 & 3.882 & 47.765 \\
7 & 1 & 250 & 200 & 0.25 & 0.382 & 81.347 & 8.3189 & 47.757 \\
8 & 1 & 250 & 400 & 0.5 & 0.539 & 84.290 & 5.356 & 48.062 \\
9 & 1 & 250 & 600 & 0.1 & 0.3186 & 86.473 & 10.009 & 48.288 \\
10 & 2 & 50 & 200 & 0.5 & 0.550 & 77.343 & 5.183 & 47.329 \\
11 & 2 & 50 & 400 & 0.1 & 0.419 & 79.156 & 7.540 & 47.521 \\
12 & 2 & 50 & 600 & 0.25 & 0.508 & 79.026 & 5.885 & 47.503 \\
13 & 2 & 150 & 200 & 0.25 & 0.399 & 80.206 & 7.982 & 47.656 \\
14 & 2 & 150 & 400 & 0.5 & 0.539 & 80.306 & 5.352 & 47.644 \\
15 & 2 & 150 & 600 & 0.1 & 0.344 & 82.420 & 9.226 & 47.864 \\
16 & 2 & 250 & 200 & 0.5 & 0.485 & 78.566 & 6.264 & 47.450 \\
17 & 2 & 250 & 400 & 0.1 & 0.333 & 83.753 & 9.541 & 48.009 \\
18 & 2 & 250 & 600 & 0.25 & 0.390 & 82.486 & 8.142 & 47.872 \\
\hline
\end{tabular}

Calculated $\mathrm{S} / \mathrm{N}$ values for each factor effecting of surface roughness are shown in Table 5. Highest values were choosen for defining minimum surface roughness. Therefore A2, B3, C1, D1 were determined optimum choice for the best surface roughness (Table 5 ). $\mathrm{S} / \mathrm{N}$ ratios data for surface roughness were seen on the graph in figure 5 . According to Figure 5 when applying force $(250 \mathrm{~N})$ and number of passes (2) level be maximum also speed $(200 \mathrm{rpm})$ and feed rate $(0.1 \mathrm{~mm} / \mathrm{min})$ level be minimum the best surface roughness value was obtained. Calculated $\mathrm{S} / \mathrm{N}$ values for each factor effecting of vickers hardness are shown in Table 6. Highest values were choosen for defining maximum hardness. Therefore A1, B3, C3, D1 were determined optimum choice for the best hardness (Table 6).

Table 5. Optimum $\mathrm{S} / \mathrm{N}$ ratios for surface roughness

\begin{tabular}{|l|ccc|}
\hline factor/level & $\mathbf{1}$ & $\mathbf{2}$ & $\mathbf{3}$ \\
\hline Passes (A) & $6.431 \mathrm{~B}$ & $\mathbf{7 . 2 3 5}$ & \\
Force (B) & 5.578 & 6.983 & 7.938 \\
Speed (C) & 7.175 & 6.568 & 6.755 \\
Feed rate (D) & $\mathbf{8 . 6 0 3}$ & 6.991 & 4.905 \\
\hline
\end{tabular}

$\mathrm{S} / \mathrm{N}$ ratios data for vickers hardness were seen on the graph in figure 6. According to Figure 6 when applying force $(250 \mathrm{~N})$ and speed $(600 \mathrm{rpm})$ level be maximum also number of passes (1) and feed rate $(0.1 \mathrm{~mm} / \mathrm{min})$ level be minimum the best vickers hardness value was obtained. But all of factors and levels, there is no significant changing on hardness values.

Table 6. Optimum S/N ratios for hardness

\begin{tabular}{|l|ccc|}
\hline Factor/level & $\mathbf{1}$ & $\mathbf{2}$ & $\mathbf{3}$ \\
\hline Passes (A) & $\mathbf{4 7 . 8 4 4}$ & 47.650 & \\
Force (B) & 47.592 & 47.742 & $\mathbf{4 7 . 9 0 7}$ \\
Speed (C) & 47.593 & 47.779 & $\mathbf{4 7 . 8 6 9}$ \\
Feed rate (D) & $\mathbf{4 7 . 8 4 1}$ & 47.707 & 47.695 \\
\hline
\end{tabular}


As is seen from Fig 7a when applying force increasing and feed rate decreasing surface roughness was improved. A few changing was obtained on surface roughness using different forces. But especially feed rate was defined impressive factor for surface roughness.

As shown in fig $7 \mathrm{~b}$ when using speed are raising surface roughness was reached slightly better value. But decreasing feed rate significant changing on surface roughness was observed. The increasing number of passes 1 to 2 the surface roughness was decreased. This is similarly the results of experiments by Revankar et al (Revankar et al., 2014). But differently further increasing number of passes they were found decreasing on surface roughness values (Fouad, 2011). When the force increasing from $50 \mathrm{~N}$ to 250 $\mathrm{N}$ the burnishing process resulting in an enhanced surface roughness. The reason for this decreasing on surface roughness with increasing force due to increased pressure between specimen and ball. Therefore the plastic deformation region broadens and raising metal diffusion was filled emptiness on specimen (Nemat and Lyons, 2000; De Lacalle et al., 2007; Klocke et al., 2009; Tadic et al., 2013). The raise on the speed level surface roughness decreasing with an effect of temperature and vibration the increasing of speed beyond a certain limit may influence of metal flow on specimen leading to raising surface roughness (El-Taweel and El-Axir, 2009).

Force

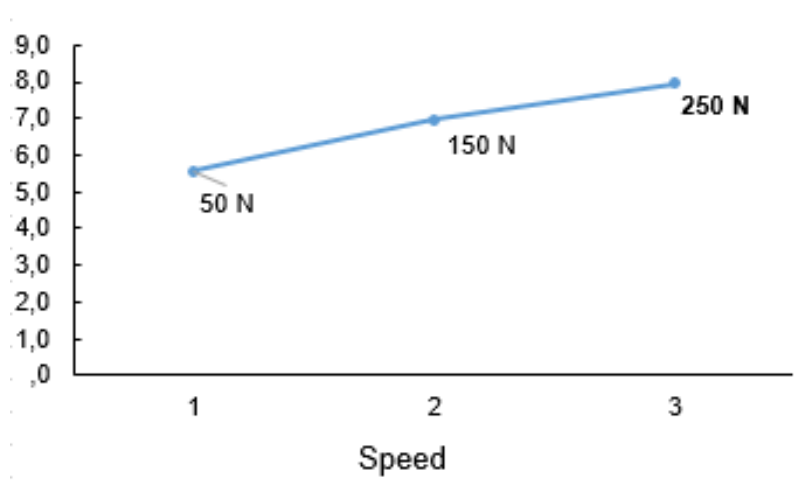

Passes

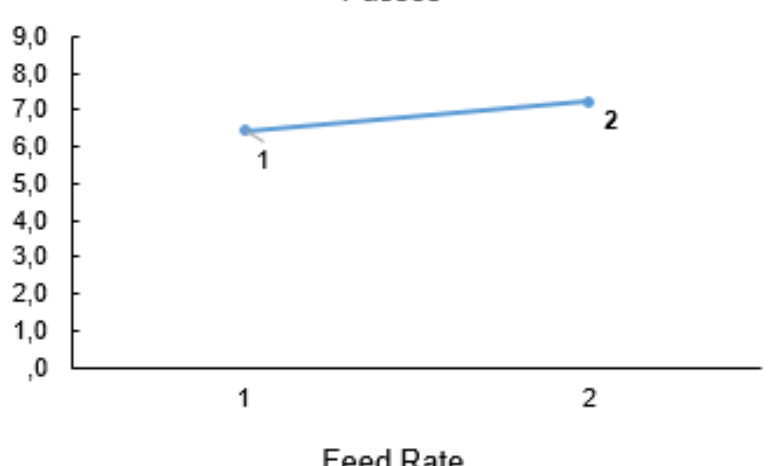

Feed Rate

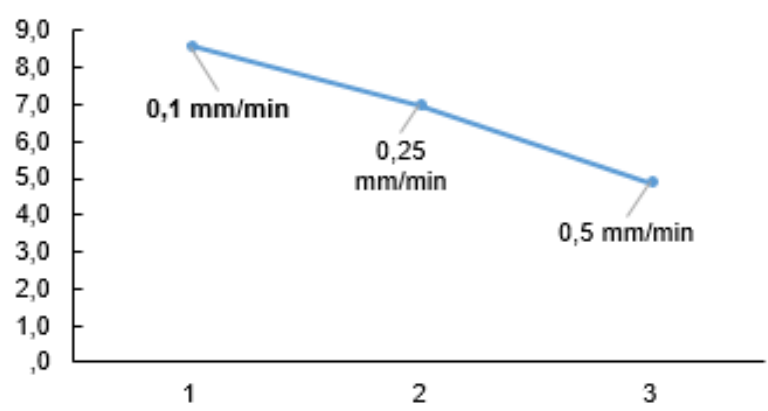

Figure 5. Plots of $\mathrm{S} / \mathrm{N}$ ratios for surface roughness 


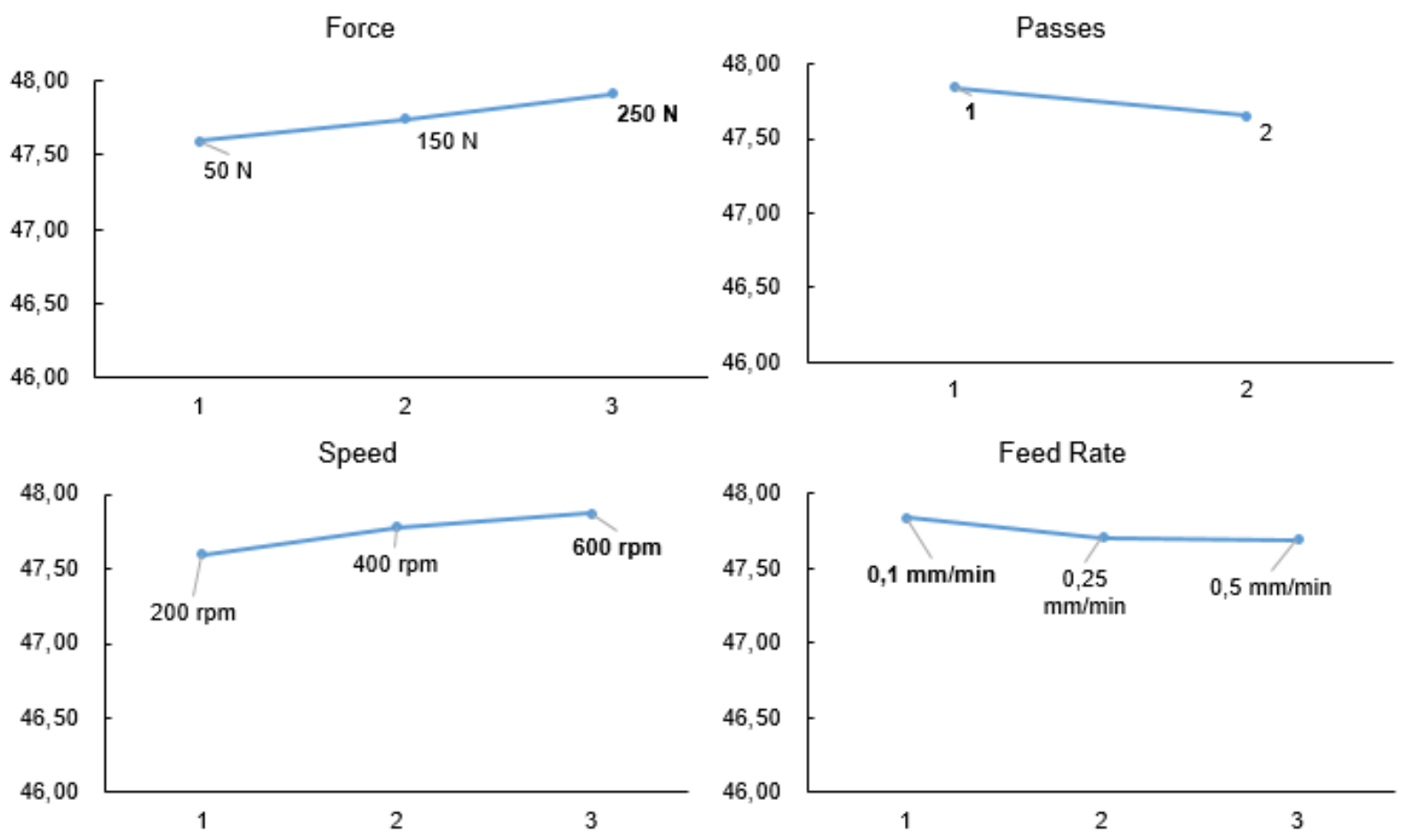

Figure 6. Plots of $\mathrm{S} / \mathrm{N}$ ratios for hardness

a)

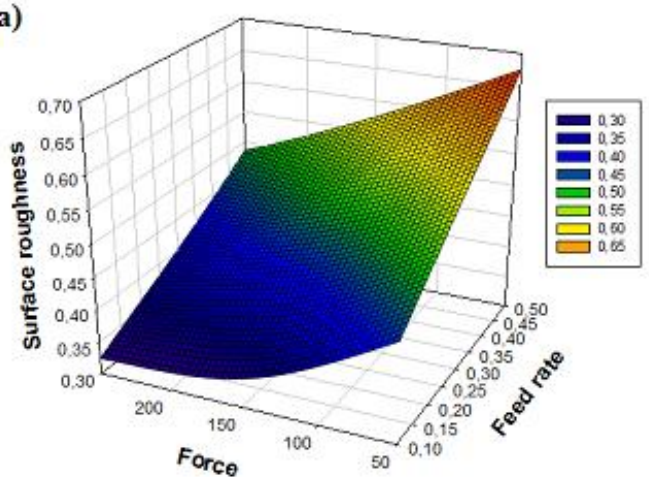

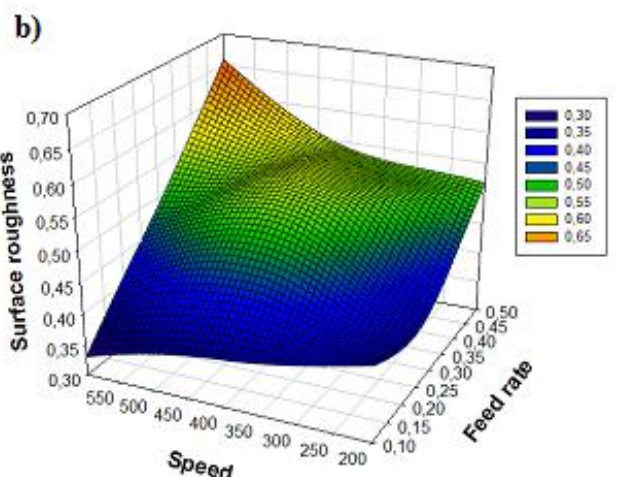

Figure 7 a) Effect of burnishing force and burnishing feed rate on surface roughness b) Effect of burnishing speed and burnishing feed rate on surface roughness

Surface roughness improve the increasing feed rate was caused gradually decreasing on surface roughness this is because deformation of the specimen is bigger and metal flow is equal at lower feed (El-Axir, 2000). For evaluating effect of number of passes on hardness value 2 level was selected. From 1 to 2 passes hardness value decreasing because of much more stiffening and as a result of flaking of the surface due to more repeated ball contact on the same sample surface (El-Axir et al., 2008). An increase in force from $50 \mathrm{~N}$ to $250 \mathrm{~N}$ the hardness gradually increases. Because of the rise in metal flow that cause to an improve deformation and fill the cavity on workpiece (Nemat and Lyons, 2000). When applying speed increases the hardness value is increases from $200 \mathrm{rpm}$ to $600 \mathrm{rpm}$. This results of experiments similarly results of experiments performed by Nemat. Also Nemat was found further increase of speed will caused decreasing surface hardness due to vibration and short contact time between ball and workpiece at higher speeds (Nemat and Lyons, 2000). According to our results, feed rate increases from $0,1 \mathrm{~mm} / \mathrm{min}$ to $0,5 \mathrm{~mm} / \mathrm{min}$ the hardness decreases because of the low deformation and irregular metal 
flow (El-Axir et al., 2008). The optimal results of each factor, both surface roughness and hardness was shown in table 7.

Table 7. Optimal values of parameters

\begin{tabular}{|l|cccc|}
\hline $\begin{array}{l}\text { factor/ } \\
\text { level }\end{array}$ & $\begin{array}{c}\text { Num. of } \\
\text { passes }\end{array}$ & Force & Speed & Feed rate \\
\hline $\begin{array}{l}\text { Surface } \\
\text { roughness }\end{array}$ & 2 & 3 & 1 & 1 \\
Hardness & 1 & 3 & 3 & 1 \\
\hline
\end{tabular}

\section{CONCLUSION}

In this study, effecting of burnishing parameter like feed rate, force, speed and number of passes on surface roughness and hardness of AZ31B Mg alloys was investigated. The results show that applying force and feed rate was determined significant factor on surface roughness. Increasing number of passes was improved surface roughness but it was caused deteriorate on hardness. The raise in force was enhanced both surface roughness and hardness. The lower level of feed rate was reached better surface roughness and hardness values. The increasing on speed was promoted surface hardness however this increasing was resulted decreasing on surface roughness. In our experiments, optimum results for surface roughness was defined as the burnishing force of $250 \mathrm{~N}$, the burnishing feed rate of $0,1 \mathrm{~mm} / \mathrm{min}$, the burnishing speed of $200 \mathrm{rpm}$ and burnishing passes of 2 . For surface hardness, the burnishing force of $250 \mathrm{~N}$, burnishing feed rate of $0,1 \mathrm{~mm} / \mathrm{min}$, burnishing speed of $600 \mathrm{rpm}$ and burnishing passes of 1 was obtained best results.

\section{REFERENCES}

Aldas, K., Özkul, I., Eskil, M., 2014, "Prediction of Surface Roughness in Longitudinal Turning Process by a Genetic Learning Algorithm", Materials Testing, Vol. 56, pp. 375-380.

Cui, Z., Shi, H., Wang, W., Xu, B. 2015, “Laser Surface Melting az31bb Magnesium Alloy with Liquid Nitrogen-Assisted Cooling", Transactions of Nonferrous Metals Society of China, Vol. 25, pp. 14461453.

De Lacalle, L. N., Lamikiz, A., Sanchez, A., Arana, J. L., 2007, “The Effect of Ball Burnishing on HeatTreated Steel and Inconel 718 Milled Surfaces", The International Journal of Advanced Manufacturing Technology, Vol. 32, pp. 958-968.

El-Axir, M., 2000, "An Investigation into Roller Burnishing”, International Journal of Machine Tools and Manufacture, Vol. 40, pp. 1603-1617.

El-Axir, M. H., Ibrahim, A., 2005, "Some Surface Characteristics due to Center Rest Ball Burnishing", Journal of Materials Processing Technology, Vol. 167, pp. 47-53.

El-Axir, M., Othman, O., Abodiena, A., 2008", Improvements in Out-of-Roundness and Microhardness of Inner Surfaces by Internal Ball Burnishing Process", Journal of Materials Processing Technology, Vol. 196, pp. 120-128.

El-Taweel, T., El-Axir, M., 2009, "Analysis and Optimization of The Ball Burnishing Process Through the Taguchi Technique", The International Journal of Advanced Manufacturing Technology, Vol. 41, pp. 301-310.

Fouad., Y, 2011, “Fatigue Behavior of a Rolled AZ31B Magnesium Alloy after Surface Treatment by EP and BB Conditions", Alexandria Engineering Journal, Vol. 50, pp. $23-27$.

Fouad, Y., El Batanouny, M., 2011, “Effect of Surface Treatment on Wear Behavior of Magnesium Alloy AZ31B", Alexandria Engineering Journal, Vol. 50, pp. 19-22. 
Gomez-Gras, G., Travieso-Rodriguez, J. A., Jerez-Mesa, R., 2015, “Experimental Characterization of the Influence of Lateral Pass Width on Results of a Ball Burnishing Operation", Procedia Engineering, Vol. 132, pp. 686-692.

Hassan, A. M., 1997, “The Effects of Ball-and Roller-Burnishing on the Surface Roughness and Hardness of Some Non-Ferrous Metals", Journal of Materials Processing Technology, Vol. 72, pp. 385-391.

Hassan, A. M., Al-Bsharat, A. S., 1996, “Improvements in Some Properties of Non-Ferrous Metals by the Application of the Ball-Burnishing Process", Journal of Materials Processing Technology, Vol. 59, pp. 250-256.

Hassan, A. M., Al-Dhifi, S. Z., 1999, "Improvement in the Wear Resistance of Brass Components by the Ball Burnishing Process", Journal of Materials Processing Technology, Vol. 96, pp. 73-80.

Hiegemann, L., Weddeling, C., Tekkaya, A. E., 2016, “Analytical Contact Pressure Model for Predicting Roughness of Ball Burnished Surfaces", Journal of Materials Processing Technology, Vol. 232, pp. 63-77.

Ibrahim, A. A., Rabbo, S. M., El-Axir, M. H., Ebied, A. A., 2009, “Center Rest Balls Burnishing Parameters Adaptation of Steel Components Using Fuzzy Logic", Journal of Materials Processing Technology, Vol. 209, pp. 2428-2435.

John, M. R. S., Wilson, A. W., Bhardwaj, A. P., Abraham, A., Vinayagam, B. K., 2016, “An Investigation of Ball Burnishing Process on CNC Lathe Using Finite Element Analysis", Simulation Modelling Practice and Theory, Vol. 62, pp. 88-101.

Klocke, F., Backer, V., Wegner, H., Feldhaus, B., Baron, H. U., Hessert, R., 2009, “Influence of Process and Geometry Parameters on the Surface Layer State After Roller Burnishing of In718", Production Engineering, Vol. 3, pp. 391-399.

Kulekci, M. K., Akkurt, A., Esme, U., Ozkul, I., 2014, “Multiple Regression Modeling and Prediction of the Surface Roughness in the Wedm Process", Materiali in Tehnologije, Vol.48, pp. 9-14.

Nemat, M., Lyons, A., 2000, “An Investigation of the Surface Topography of Ball Burnished Mild Steel and Aluminium", The International Journal of Advanced Manufacturing Technology, Vol. 16, pp. 469473.

Pu, Z., Outeiro, J. C., Batista, A. C., Dillon, Jr. O. W., Puleo, D. A., Jawahir, I. S., 2012, “Enhanced Surface Integrity of AZ31BB Mg Alloy by Cryogenic Machining Towards Improved Functional Performance of Machined Components", International Journal of Machine Tools and Manufacture, Vol. 56, pp. 17-27.

Revankar, G. D., Shetty, R., Shrikantha, S., Vinayak, R., Gaitonde, N., 2014, “Analysis of Surface Roughness and Hardness in Ball Burnishing of Titanium Alloy", Measurement, Vol. 58, pp. 256268.

Rodriguez, A., Lopez de Lacalle, L. N., Celaya, A., Lamikiz, A., Albizuri, J., 2012, “Surface Improvement of Shafts by the Deep Ball-Burnishing Technique", Surface and Coatings Technology, Vol. 206, pp. 2817-2824.

Sagbas, A., 2011, "Analysis and Optimization of Surface Roughness in The Ball Burnishing Process Using Response Surface Methodology and Desirabilty Function", Advances in Engineering Software, Vol. 42, pp. 992-998.

Shiou, F., Cheng, C., 2008, “Ultra-precision Surface Finish of NAK80 Mould Tool Steel Using Sequential Ball Burnishing and Ball Polishing Processes" Journal of Materials Processing Technology, Vol. 201, pp. 554-559.

Shiou, F. J., Hsu, C. C., 2008, "Surface Finishing of Hardened and Tempered Stainless Tool Steel using Sequential Ball Grinding, Ball Burnishing and ball Polishing Processes on a Machining Centre", Journal of Materials Processing Technology, Vol. 205, pp. 249-258.

Tadic, B., Todorovic, P. M., Luzanin, O., Miljanic, D., Jeremevic, B. M., Bogdanovic, B., Vukelic, D., 2013, "Using Specially Designed High-Stiffness Burnishing Tool to Achieve High-Quality Surface Finish", The International Journal of Advanced Manufacturing Technology, Vol. 67, pp. 601-611. 